\title{
Nurcholish Madjid's thoughts on Islamic politics in Indonesia
}

\author{
Choeroni ${ }^{1}$ and Azwan Pratama ${ }^{2}$ \\ \{choer.indah@gmail.com ${ }^{1}$, azwanpratama1@gmail.com ${ }^{2}$ \} \\ ${ }^{1,2}$ Sultan Agung Islamic University (UNISSULA) Semarang, Indonesia
}

\begin{abstract}
This article focuses on the thoughts of Nurcholish Madjid (Cak Nur) on Islamic politics in Indonesia. Based on the library research and using qualitative descriptive approach to explore how Cak Nur see the relation of state and Islam. According to him, a strong Islamic orientation is always associated with opposition to the government. He also explained that Islam itself is not a theory or ideology. He further said that in the field of politics, Islam is in a position that accompanies sharia and is closer to philosophy with its own dynamics and characters. The concept of an Islamic State is a distortion of proportional relations between religion and the State. The state is one aspect of worldly life whose dimensions are rational and collective, while religion is an aspect of life whose dimensions are spiritual and personal. Islamic politics, according to Nurcholis Madjid, is not intended as an application of politics and turning Muslims into politicians, but it is intended to globalize the values that are supposed to be worldly, and to release Muslims from the tendency to put them into the life-after matters (ukhrawi). Thus, the mental willingness to always test and re-examine the truth of a value in the face of material facts, moral or historical, becomes the nature of the Muslims.
\end{abstract}

Keywords: Nurcholish Madjid, Politics, Islam, Philosophy, Indonesia.

\section{Introduction}

Islam is a religion that guides people to the right path for life in society or country. Islam not only provides spiritual teachings but also provides guidance on how social and state relationships are. There are three beliefs between Islam and constitution. First, Islam is not merely a religion in the Western sense, which is only about the relationship between man and God, but Islam is a perfect and compprehensive religion with regulation for all aspects of human life including the matters of state. Secondly, it is argued that Islam is a religion, in the Western sense, which has nothing to do with state affairs. Thirdly, rejecting the view that Islam is a comprehensive religion and that there is a system of constitution in Islam. Furthermore, this beliefs also rejects the notion that Islam is a religion, in the Western sense, which only regulates the relationship between man and his Creator. This belief states that in Islam there is no constitutional system, but a set of ethical values for state [1]. Bachtiar Effendy stated that Islam is a multi-interpretive religion, where Islam is able to go along with modern political development, or vice versa. This study discusses on where Islam is analyzed, and which beliefs are used to analyze it [2].

The Qur'an does not explicitly explain the formation of a State and the government system that must be enacted. What is important is that Islamic teachings can be applied in 
society [3]. M. Amin Rais added that there is no command in the Qur'an and al Sunnah which states to establish an Islamic state. This shows that the eternity of the revelations of which contain the basic ethics, as well as the norms, are then submitted to humans for the details to be analyzed with the way of ijtihad [4].

Further in this case, Cak Nur as a moderate thinker that underlies his understanding that Islam only provides a code of ethics on how politics is run based on the principles contained in it. Islam teaches monotheism and upholds the values of justice, equal rights and obligations, and peace, for the benefit of the whole community [5]. He also stated that the emergence of Islamic political ideas or Islam as the basis of politics was due to the form of apologetic tendencies. This apology, grows from two lines, first, apology which is because of Western ideology, such as democracy, socialism, communism and so on and second, because of legalism which is an all-legalistic appreciation of Islam. In legalistic perception, Islam is seen as merely a structure and a collection of laws. This tendency of legalism for Cak Nur is rooted in fiqhism. Whereas, the view that arises from the codification of the laws of thought of Islamic scholars in the second and third centuries of hijriah, is possible to cause jurisprudence to lose its relevance to the patterns of modern society which are constantly changing and developing in various dimensions [6].

Thus, in principle, the concept of Islamic politics, according to Cak Nur's belief, is a distortion of proportional relations between politics and religion. Politics is one aspect of worldly life, whose dimensions are rational and collective [7]. Whereas religion, according to him, is another aspect of life, which has spiritual and personal dimensions. Therefore, it is not surprising that Cak Nur does not agree that Islam is seen as an ideology. For him Islam is not an ideology because the direct view of Islam as an ideology can mean degrading the religion to the same level as the various ideologies that exist in the World.

\section{The Thoughts of Nurcholis Madjid on Islamic politics}

Thoughts of Cak Nur, often involve two themes at once, that is about religious matters and state issues. In state matters, Cak Nur often tries to give ideas which are neglected by politicians. Islamic politics is one of them, which becomes the critical attitude of Cak Nur as an intellectual who is deeply in need of a democratic system that moves around us. The intended process of democracy is if it is able to open the dynamics of public scrutiny and balance [8]. Cak Nur explained that there is a relationship between religion and the state which is still indirect, that is at the level of political thought. Religion provides support for political values that bring mutual benefit. According to him, due to the nature of the state that should be neutral from religion, the political languages used must also be universal. Cak Nur classifies these political thoughts in several themes of thought, namely democracy, justice and openness [1].

\subsection{Thoughts about Democracy}

One of Cak Nur's thoughts is to highlight the issue of democratization in Indonesia. This democracy means that if he opens the supervision and balance of the community. The formulated democracy is "once for everlasting" of which is not to give room for development and change is actually not democracy, but dictatorship. In the procedure of democracy explained by Cak Nur, it feels that the broad political participation and autonomy from the 
community is strongly necessary [2]. Although liberal democracy or popular democracy has many shortcomings, manipulations, pretensions in the real way of working; but there is no denying how the principle of sanctification of power and credibility related to that principle is maintained where freedom of thought, criticism, self-expression is guaranteed without limitations, for all citizens [4]. The followings describe some of the themes of Cak Nur's thoughts related to the matters of democratization in Indonesia. They are:

\subsubsection{Opposition}

Opposition according to Cak Nur does not need to be understood as an opposition (to oppose does mean to oppose), because in opposition there is also a facet to support it, so that in the context of political opposition it means more as a balancing force, a check and balance that can make the blocked feelings uttered. Basically, the need for opposition can begin with a very simple postulate, of which social and political problems cannot be at stake with good intentions, with whatever the claims of those people have good intentions, because the lives of many people are at stake and if something social in nature involves many people, it must be perceived, understood, and viewed as an open issue, where participation becomes a form of necessity. One form of participation is opposition, which is a socio-political activity that reminds us not to be fatal victims for a simple reality; that humans can always be wrong [7]. Cak Nur added that the opposition was also family-friendly, but it does not mean that the family can not remind each other, remembering and reminding are a simple form of check and balance. So that the opposition does not conflict with concensuses [9]. Democracy is an open ideology of which opens the door widely for changes and development, through mutual experimentation. Therefore, democracy is the only system which is capable of correcting itself and making improvements and changes towards progress for itself. Democracy is a system that is open to all actors and participants, and it is not right to be submitted to personal desire or discretion of how wise the person is. Why offsetting is necessary is because the system can be said to be a democratic society only if it opens the opportunity for every group in society to participate, with any and whatever the way, and should not be allowed a group or some groups to dominate the whole. This mechanism that makes democracy in America, for example, is not entirely a "majority tyranny" as said by Alexis de Tocqueville [7].

\subsubsection{Principles of Deliberation}

Basically the principle of deliberation will not work productively without freedom of expression, which in the modern order the life of society and state is institutionalized, among others, in academic freedom and freedom of the press, but the principle of deliberation will also be undermined by absolutistic attitudes and desire to dominate discourse because there is no feeling humble enough to see the possibility of others being on a better or more right side. The true deliberation is deliberation which takes place on the basis of freedom and humanitarian responsibility: the basis of the order of society and a democratic state. Therefore, democracy with the right deliberation as a basis will not be realized without a strong view of human equality or egalitarianism and will end up due to the existence of rigid and a priori social stratification in paternalistic and feudalistic systems.

\subsubsection{Pluralism}

Pluralism becomes an important theme that has received a lot of attention from a number of Muslim scholars, including Cak Nur because Indonesia is viewed an archipelago in terms of geographics. Besides, socially, Indonesia consists of a variety of ethnicities, languages, and customs that show a very high level of pluralism. On the other hand, Indonesian culture cannot be separated from the touch of the influence of beliefs and religions of which develop within. 
Therefore, political maturity is needed such as the ability to accept differences, and resolve these differences within the limits of political civilization, because all of this is important for democracy. According to Cak Nur, pluralism must be understood as the true connection of diversity in the bonds of civility (genuine engagement of diversities within the bonds of civility) meaning that pluralisme is an order of society in which we must be willing to engage in diversity and solve problems with a situation [9].

\subsubsection{People's Sovereignty}

People's sovereignty is at the core of the general participation of the people in the life of the state. The existence of opportunity for effective public participation is a true manifestation of freedom and independence. Therefore, all the ideals of society and state as stated in the values of the noble agreement in the muqoddimah of the 1945 Constitution, will disappear meaninglessly without the general participation of the people. Even the sovereignty of the state in its relations with other countries is a continuation of sovereignty of the people. This is obviously proven once in times of critical where state is facing threats [9].

\subsection{Thought About Justice}

In principle all humans want to be treated fairly, both in the legal, political and economic fields. In our country of Indonesia, if we want to look back on the issue of injustice, it is often the cause of conflicts and disputes in Indonesian society, such as the bloody conflict in Poso Maluku and other places in Indonesia [10]. The followings are some of the themes of Cak Nur's thoughts related to justice. They are:

\subsubsection{Social justice}

Economic sovereignty is the sovereignty that is expected to be born out of social justice, which is our true goal in the state, because with social justice there will be a sense of belonging and a sense of participation perceived by all people which increase commitment to efforts to realize social justice, with a firm regard to the real interests of people's lives. The most bitter lesson from our experience of the state lately arises because of the negligence of the value of social justice, where practices of social injustice occur and rampant freely [11]. For the sake of those happpenings, economic development must be changed from the patterns and orientations which are too wide to open vulnerability to the sovereignty of the people, to become a pattern and economic orientation of patriotic people. The economic resilience of society will be realized if we are able to independently process our natural wealth, with the highest level of creativity. National economic independence is manifested by advanced and modern people's agricultural economics, and with the people's industrial base. In the global economic system, something that cannot be avoided only with the national economic resilience is that we will be able to compete in a healthy manner, with the ultimate result of victory for all, without harming any party. And with the toughness of the national economy as well, we will be more protected from the destructive elements of greed of international economic adventurers [12].

\subsubsection{Legal compliance}

Personal commitment to noble values of life will be meanless if it is not manifested in reality in daily actions. Personal commitment to noble values can be realized in the form of personal obedience to the applicable legal rules. All members of society must submit and obey the law with a firm, consistent, disciplined and patient attitude and fortitude. Once a rule or 
law is violated, the rule of law principle has been undermined, with however small the rules violated are, even if for example "just" the provisions which must stop at a red light on the road [4].

\subsubsection{Eradication of corruption}

Gunnar Midral, a Swedish economist who won the Nobel Prize, as quoted by Cak Nur included Indonesia in a group of developing countries, as a "soft countries" group. What is meant by "soft" is that there is no social discipline, and abuse of authority for personal interest practiced by people who have economic, social and political power. The chance of power abuse in large portion is open to the upper class, but people from the lower classes also often get opportunities for small benefits, and this is called a symptom of corruption. Corruption is a political system, which can be directed by those in power with a degree of accuracy that can be tolerated. The worst effects of increasing corruption are the spread of cynicism in the wider community and the decreasing willingness to resist the temptation of accepting bribes at all levels of the bureaucracy. Corruption also introduces irrational elements in planning and implementing plans (e.g. development) by distorting the plan. Because of the complexity of the facts about corruption, and the detriment of the resulting impacts, there is no way to eradicate corruption except from strong political will and exemplary leaders. Strong political will and exemplary leaders must be in line and together [9].

\subsection{Thought About Openness}

One thing that we deserve to be thankful to God is the agreement that Pancasila is an open ideology. Pancasila is a modern ideology, manifested in modern times and displayed by a person or group of people with modern insights, namely the founding father of the Republic of Indonesia, and is intended to provide a common philosophical foundation for a modern plural society, namely the Indonesian people. As a product of the modern mind, Pancasila is a dynamic ideology due to the dynamic character which makes Pancasila understood and viewed as an open ideology. Therefore, it is impossible for Pancasila to be viewed as one-time interpretation for ever (one of all), Pancasila does not allow the existence of a single body that monopolizes the right to interpret it either [9]. Below are some of the themes of Cak Nur's thoughts that are related to openness, among others are:

\subsubsection{Social and Political Views}

The essence of the reform movement is the criticism of the current state of affairs, and the effort to get a better form. Because of that logic, a reform cannot be started from zero or nothingness, for however radical and fundamental the improvement is sought. The reform movement must be viewed as a normal and natural continuation of the level of community pluralism and the dynamics of its development [9]. According to Nurcholish Madjid, this sociopolitical view is valid, as long as it does not categorically fight and obstruct the spirit of meeting the common good among all groups without discrimination or differentiation from one another.

\subsubsection{Principles of Life Guidance}

The principle of life guidance required by an independent society is loyalty to conscience. Since the source voice of conscience is forever individual, then the loyalty to conscience involves the protection of the freedom of conscience. In its sequence, freedom of conscience takes a manifest form of religious freedom. Because with the teachings of religion, 
through faith and devotion to the Supreme Lord, the purity of conscience is confirmed [9]. In the way of politics, Cak Nur said that a strong Islamic orientation was always associated with opposition to the government. According to him, this is because Islam plays a consistent role as an ideology (rallying ideology) of colonialism. This role resulted in national independence. because Muslims put forward political ideas that are not suitable and not built with practical guidance of the present era, so that there is a growth pf Islamic-oriented political prejudice with a national-oriented government (Nurcholish, 1887). Nurcholis Madjid also rejected the concept of the Islamic State, which he emphasized in the second cultural lecture at Taman Ismail Marzuki in 1972, in which part of the lecture content was actually his thoughts on the Islamic epistemology, especially regarding with the two approaches, namely the religious approach which concerns religious issues of life-after matters (ukhrawi) and a scientific approach that encompasses worldly problems, both about material and social nature. The faith approach produces worship to God which will have an impact on the perfection of human virtue while the scientific approach must be empirically rational which results in the concept of pious deeds.

Cak Nur also criticized the concept of an Islamic State which he regarded as an apologia. according to him there is a reason why Muslims behave apologically towards their thoughts. First, their defensive attitude towards the invasion of western (modern) ideologies, such as democracy, socialism and so on which are totalitarian. Muslims respond to the invasion with the concept of aldin which includes the unity of religion and the State, but not based on scientific studies, only illusive apologia. second, the understanding of legalism which is only produced by the guidance of the fiqh approach so that the State is judged as a legal structure called the Shari'a. According to him, studies of fiqh studies in modern times have lost their relevance to the problems of society which are constantly changing.

The state, for example, is a symptom that has an objective national dimension, while religion has a spiritual dimension that is personal, both are interrelated, but still differentiated. If the State participates in regulating matters of religion and belief, then this is not in accordance with the teachings of Islam itself which does not recognize religious authority (larahbaniyyah fi al Islam) there is no priesthood authority in Islam [11-14].

In the matter of leadership according to Islam, Nurcholis Madjid also said that harmonious cooperation between the community and the leader is a must, because there are strengths and weaknesses in human beings at the same time. Strength is obtained because the nature of purity originates in nature, which makes it always has the potential to be right and good. The weakness is caused by the fact that humans were created by God as weak beings, short of mind and narrow in view and easy to complain. Humans can increase their strength in cooperation, and can minimize their weaknesses through cooperation.

Cak Nur also mentioned in the present context, the main requirement for leaders is to be able to develop a tradition of two-way dialogue, not patronize and also not to be provocative, so the atmosphere of the openess will be a necessity. Cak Nur compared the old order leadership model with the reform era where he said that the concept of the old order leadership which tended to be a dictator as well as the new order was no longer suitable to be used today or in the future. He said that the ideological content on Islam should be discarded, thus, Islam as ad-din will not experience a reduction in its meaning. According to Nurchalis Madjid, Islam must be defined more inclusive which includes anyone in his faith system, including Muslims [15]. 


\section{Conclusion}

Nur Cholis Madjid or better known as Cak Nur is a contemporary Islamic thinker. He wrote many works to realize his thoughts which up to now still become one of the foundations of scholars as a reference in expressing their ideas. Cak Nur is a reformer of Islamic thought in Indonesia. There are three factors that influence the idea of renewal. They are the religious factors, political factors and economic factors which are affecting Muslims, especially in Indonesia. Politics in Indonesia intrigue Cak Nur for the need to express ideas in matters related to the relationship between religion and the State. Cak Nur classifies these political thoughts in several themes of thought, namely democracy, justice and openness. Related to the issue of democratization in Indonesia, he mentioned several themes such as the need for opposition, the principle of deliberation, the importance of pluralism and the sovereignty of the people. In relation to the thought of justice, he outlines the following themes; the need for social justice, the need for legal order and the obligation to eradicate corruption. In terms of the idea of openness, he revealed several important themes namely; socio-political views and the necessity of the principle of life guidance. Cak Nur said that there are three main issues that must be faced by Muslims in the world of politics. They are first the need for an attitude of secularization, second, the need for a more free way of thinking for Muslims and third, the need for ideas of progress and a more open attitude towards other people.

\section{References}

[1] Azhar, M. (2013). Epistemologi Politik Islam Tentang Wewenang dan Kekuasaan. Jurnal Studi Islam, 14, 1-8.

[2] Ahmad A. Sofyan \& M. Roychan Madjid, (2003). Gagasan Cak Nur tentang Negara dan Islam, Yogyakarta: Titian Ilahi Press, 169.

[3] Bachtiar Effendy, (1998).Islam dan Negara: Transformasi Pemikiran dan Praktik Politik Islam di Indonesia, Jakarta: Paramadina, 16.

[4] Edy A. Effendi, (1998) Dialog dan wacana keterbukaan, pengantar dalam Nurcholish Madjid, Dialog Keterbukaan; Artikulasi Nilai Islam dalam Wacana Sosial Politik Kontemporer, Jakarta:Paramadina, Cet. ke-1, xvi

[5] Lismijar. (2007). Relasi Agama dan Negara; Analisis Politik Nurcholish Madjid. Kalam; Jurnal Agama Dan Sosial Humaniora, 5(2), 23-42.

[6] Muhammad Hari Zamharir, (2004). Agama dan Politik; Analisis Kritis Pemikiran Politik Nurcholis Madjid, Jakarta: Rajawali Press, 63.

[7] M. Amin Rais, (1989).Cakrawala Islam: antara Cita dan Fakta,Bandung: Mizan, 41.

[8] M. Dawam Rahardjo, (2010).Merayakan Kemajemukan Kebebasan dan Berkebangsaan, Jakarta: Kencana Media, 47.

[9] Nurcholish Madjid, (1999). Cita-cita Politik Islam Era Reformasi, Jakarta: Paramadina, 134-136.

[10] (1998). Dialog Keterbukaan Artikulasi Nilai Islam dalam Wacana SosialPolitik Kontemporer, Jakarta: Paramadina, Cet. ke-1, 183-199.

[11] Noorhaidi Hasan. (2007). Islamic Militancy, Sharia, and Democratic Consolidation in PostSuharto Indonesia. Nanyang Technological University Library, 143, 1719-1722. https://doi.org/10.1063/1.2978249

[13] Nurrohman. (2011). Politik Islam dalam Cita dan Realita. Jurnal Al-Qurba, 2(1), 14-30.

[14] Shalihin, N. (2008). Rationalism and Future Political Islam in Indonesia. Journal of Government \& Politics, 4, 88-106. https://doi.org/10.18196/jgp.2013.0006

[15] Syarif, Z. (2013). Masa depan politik Islam. Jurnal Millah, XIII, 73-90. 